\title{
Influence of Nematicide Application on the Severity of the Root-Knot Nematode-Fusarium Wilt Disease Complex in Cotton
}

\author{
P. D. Colyer, Louisiana Agricultural Experiment Station, Red River Research Station, P.O. Box 8550, Bossier City \\ 71113-8550; T. L. Kirkpatrick, Arkansas Agricultural Experiment Station, Southwest Research and Extension \\ Center, Hope 71801; and W. D. Caldwell and P. R. Vernon, Louisiana Agricultural Experiment Station, Red River \\ Research Station, P.O. Box 8550, Bossier City 71113-8550
}

\begin{abstract}
Colyer, P. D., Kirkpatrick, T. L., Caldwell, W. D., and Vernon, P. R. 1997. Influence of nematicide application on the severity of the root-knot nematode-Fusarium wilt disease complex in cotton. Plant Dis. 81:66-70.

Eight cotton cultivars, with and without aldicarb treatment, were evaluated for their effect on the severity of the root-knot nematode-Fusarium wilt disease complex in cotton. A randomized complete block design with a split-plot arrangement of treatments was used with cotton cultivars as the main plots and nematicide treatments as the subplots. Results in 1994 and 1995 were similar. Yield of lint, boll weight, and wilt and root-gall ratings were different among cultivars and between nematicide treatments both years. Increased lint yield and boll weight, and reduced root-gall and wilt ratings were associated with application of aldicarb. Increased lint percentage was associated with application of aldicarb in 1994, but not in 1995. Fiber micronaire, elongation, uniformity, and strength were different among cultivars, but not between nematicide treatments. Fiber length (UHM; Upper-Half Mean) was different among cultivars and was higher in the aldicarb-treated plots in both years. Numbers of Meloidogyne incognita second stage juveniles and eggs extracted from soil samples were lower in the aldicarb-treated plots in July, but not at harvest, both years. Population densities of $M$. incognita were not different among cultivars, except the mid-season sample in 1995.
\end{abstract}

Additional keywords: disulfoton, Fusarium oxysporum f. sp. vasinfectum

The root-knot nematode-Fusarium wilt disease complex in cotton (Gossypium hirsutum L.) is a serious disease that can result in plant mortality and reduced cotton yields. Both pathogens can damage plants independently, but losses are more severe when they occur together $(2,12,16,17)$. Management strategies for this disease complex include rotations with crops that are poor hosts for the nematode, planting cotton cultivars that are resistant to either the nematode or the fungus, and soil fumigation $(5,7,13)$. Use of rotations to reduce the complex has been of limited value because Fusarium oxysporum Schlechtend.: Fr. f. sp. vasinfectum (Atk.) W. C. Snyder \& H. N. Hans. is a good saprophyte, and also is able to survive in soils for several years on the roots of nonhost plants (20). In addition, the root-knot nematode ( $\mathrm{Mel}$ oidogyne incognita (Kofoid \& White)

Corresponding author: P. D. Colyer

E-mail: Pcolyer@1suvm.sncc.lsu.edu

Approved for publication by the director of the Louisiana Agricultural Experiment Station as manuscript \#96-84-0170.

Accepted for publication 9 October 1996.

Publication no. D-1996-1031-04R

(C) 1997 The American Phytopathological Society
Chitwood) has a broad host range and there are few economically viable alternative crops for use by cotton producers in a rotation program.

The effectiveness of planting resistant cultivars to control the disease complex has been diminished by the lack of high levels of resistance to both the fungus and the nematode in available cultivars. Although some cultivars have resistance to Fusarium wilt $(6,10,19,22)$, none are immune to the pathogen (7). There also is little resistance to the root-knot nematode in commercial cotton cultivars $(3,18,22)$. Furthermore, because root-knot nematodes can induce susceptibility to wilt in normally resistant cultivars $(15,16)$, cotton cultivars with resistance to Fusarium wilt may not be adequate to reduce losses when the complex is present.

Soil fumigation has been successful in reducing nematode populations, resulting in a decrease in wilt incidence $(9,11)$; however, fumigant nematicides are expensive and not always economical for cotton production (7), and their availability in the future is uncertain. Nonfumigant nematicides can be applied in the planting furrow, but the activity of nematicides is limited to a few weeks after planting. There is little information on the efficacy of applying nematicides at planting on the severity of the root-knot nematode-Fusarium wilt disease complex in cotton.
The objective of this study was to evaluate the effectiveness of applying an infurrow nematicide at planting on the development of the root-knot nematodeFusarium wilt disease complex in cotton.

\section{MATERIALS AND METHODS}

The experiments were conducted at the Red River Research Station in Bossier City, LA, in 1994 and 1995. The soil was a Norwood very fine sandy loam (Typic Udifluvent: fine-silty, mixed, calcareous, thermic) with a $\mathrm{pH}$ of 6.8 , and $0.2 \%$ organic matter. The average particle size distribution was $58 \%$ sand, $37 \%$ silt, and $5 \%$ clay. Historically, cotton planted at this location has experienced a high frequency of Fusarium wilt associated with root-knot nematode infection. Prior to the initiation of this study, the population density of $M$. incognita was increased through a series of rotations with kenaf (Hibiscus cannabinus L.), an excellent host for the root-knot nematode. Experimental design was a randomized complete block with a split-plot arrangement of treatments with four replications. Main plots, which were eight rows (101 cm spacing) by $13.7 \mathrm{~m}$ in length, were cotton cultivars and subplots, which were 4 rows (101 cm spacing) by $13.7 \mathrm{~m}$ in length, were in-furrow treatments.

Eight cotton cultivars (Chembred 333, Deltapine 20, Deltapine 51, Deltapine 5690, DES 119, Hyperformer HS-46, Stoneville LA887, and Suregrow 501) with different levels of susceptibility to Fusarium wilt and the root-knot nematode were evaluated. The nematicide aldicarb (Temik 15G, Rhone-Poulenc Ag Co., Research Triangle Park, NC) was applied at planting in the seed furrow at $1.18 \mathrm{~kg}$ a.i. per hectare. Plots that did not receive aldicarb were treated with disulfoton (DiSyston 15G, Miles, Inc., Kansas City, MO) at $1.11 \mathrm{~kg}$ a.i. per hectare. Disulfoton, which has little efficacy against nematodes, was applied to control thrips and other early season insect pests that are also controlled by aldicarb. All cotton seed was commercially treated with carboxin-pentachloronitrobenzene-metalaxyl.

Cotton was planted on 20 May 1994 and 11 May 1995 at 200 seeds per 13.7-m row. Weed and insect control was according to Louisiana Cooperative Extension Service guidelines. Seed cotton was harvested from the two center rows of each plot with a 
spindle picker on 31 October 1994 and 5 October 1995. Boll samples of 50 arbitrarily selected, hand-harvested bolls from each plot were used to determine boll size, and then ginned on a 10-saw laboratory gin to determine lint percentage ([weight of lint/weight of lint plus seed] $\times 100$ ) and provide lint samples for fiber quality analysis. Fiber qualities (micronaire, length, uniformity, strength, and elongation) were determined from boll samples submitted to the Department of Agronomy, Cotton Fiber Testing Laboratory, Louisiana State University, with high volume instrumentation. Lint yield was calculated as the yield of unclean seed cotton from each plot multiplied by its lint percentage (mean of three replications), converted to weight per hectare.

Nematode populations (second-stage juveniles [J2] and eggs) were determined from a composite of 20 soil cores collected from the two center rows of each plot to a depth of $20 \mathrm{~cm}$ with a 2.5 -cm-diameter sampling tube. Soil samples were collected on 25 May, 20 July, and 1 November 1994, and 25 May, 21 July, and 3 November 1995. Nematodes were extracted from a $500 \mathrm{~cm}^{3}$ subsample by wet sieving and sugar flotation, and $\mathrm{J} 2$ of $M$. incognita were counted under a dissecting microscope (1). All root fragments in the subsample were collected and shaken for 4 min in $0.05 \% \mathrm{NaOCl}$ to free the eggs from the egg masses (8). The total number of $\mathbf{J} 2$ and eggs in each plot was recorded, and transformed $[\log (\mathrm{J} 2+$ eggs +1$)]$ for statistical analysis.

Severity of Fusarium wilt and root-knot nematode infection was rated following inspection of 10 plants per plot after harvest. Fusarium wilt severity was based on vascular stem discoloration as follows: $0=$ no vascular discoloration; $1=<10 \% ; 2=$ 11 to $25 \% ; 3=26$ to $50 \% ; 4=51$ to $75 \%$; and $5=>75 \%$ of the vascular tissue discolored. Root-knot severity was assessed as root galling as follows: $0=$ no galls; $1=$ 1 to 2 galls; $2=3$ to 10 galls; $3=11$ to 30 galls; $4=31$ to 100 galls; and $5=>100$ galls per root system. Arbitrarily selected samples of stems displaying vascular discoloration were incubated on potato-carrot agar to verify the presence of Fusarium oxysporum.

Data were subjected to analysis of variance with PC/SAS software (SAS Institute, Cary, NC). Means were separated with Duncan's new multiple range test $(P=$ 0.05).

\section{RESULTS}

In 1994, lint yield was $30 \%$ greater and percentage of lint recovered after ginning was $1.5 \%$ greater across all cultivars following treatment with aldicarb than following treatment with disulfoton (Table 1). Lint yield and lint percentage were also different among cotton cultivars $(P=$ $0.01)$, but the interaction between cultivars and in-furrow treatments was not significant $(P=0.05)$. Chembred 333 produced significantly lower lint percentage than the other cultivars. Boll weights differed among cultivars $(P=0.01)$, and in-furrow treatment with aldicarb resulted in $4 \%$ larger bolls across all cultivars (Table 2). Stoneville LA887 produced larger bolls than the other cultivars. Fiber qualities were different among cultivars (data not shown), but only length was different between in-furrow treatments (Table 2). The interaction between cultivars and in-furrow treatments was not significant for any of the fiber qualities measured or for boll weight $(P=0.05)$.

In 1995, seed cotton and lint yields were lower than in 1994. Otherwise, the relative effects of in-furrow treatments and cultivars on lint yield (Table 3), boll weight, and fiber length (Table 4) were similar to 1994, when treatment with aldicarb resulted in increases in these parameters. Lint percentage was different among culti-

Table 1. Effect of cotton cultivars and in-furrow chemicals on lint yield and lint percentage, 1994

\begin{tabular}{|c|c|c|c|c|c|c|}
\hline \multirow[b]{2}{*}{ Cultivar } & \multicolumn{3}{|c|}{ Lint (kg/ha) } & \multicolumn{3}{|c|}{ Lint $(\%)$} \\
\hline & Aldicarbw $^{w}$ & Disulfoton $^{x}$ & Mean $^{y}$ & Aldicarbw $^{w}$ & Disulfoton $^{x}$ & Mean $^{y}$ \\
\hline Chembred 333 & 892 & 653 & $773 \mathrm{bc}$ & 39.8 & 39.1 & $39.5 \mathrm{c}$ \\
\hline Deltapine 20 & 1,191 & 740 & $965 \mathrm{a}$ & 41.3 & 40.7 & $41.0 \mathrm{~b}$ \\
\hline Deltapine 51 & 1,175 & 853 & $1,015 \mathrm{a}$ & 41.1 & 40.9 & $41.0 \mathrm{~b}$ \\
\hline Deltapine 5690 & 877 & 615 & $746 \mathrm{c}$ & 41.0 & 40.6 & $40.8 \mathrm{~b}$ \\
\hline DES 119 & 1,092 & 885 & 989 a & 41.4 & 41.1 & $41.2 \mathrm{~b}$ \\
\hline Hyperformer HS-46 & 949 & 607 & $778 \mathrm{bc}$ & 41.2 & 41.0 & $41.1 \mathrm{~b}$ \\
\hline Stoneville LA-887 & 1,240 & 790 & $1,015 \mathrm{a}$ & 42.6 & 41.4 & $42.0 \mathrm{a}$ \\
\hline Suregrow 501 & 1,066 & 760 & $914 \mathrm{ab}$ & 41.7 & 41.3 & $41.5 \mathrm{ab}$ \\
\hline Mean & $1,058^{\mathrm{z}}$ & 738 & & $41.3^{z}$ & 40.7 & \\
\hline
\end{tabular}

w Temik $15 \mathrm{G}$ applied at $1.18 \mathrm{~kg}$ a.i. /ha in-furrow at planting.

${ }^{x}$ DiSyston $15 \mathrm{G}$ applied at $1.11 \mathrm{~kg}$ a.i./ha in-furrow at planting.

y Means within a column followed by the same letter are not significantly different according to Duncan's new multiple range test $(P=0.05)$.

${ }^{\mathrm{z}}$ Means significantly different at $P=0.01$.

Table 2. Effect of cotton cultivars and in-furrow chemicals on boll weight and fiber length, 1994

\begin{tabular}{|c|c|c|c|c|c|c|}
\hline \multirow[b]{2}{*}{ Cultivar } & \multicolumn{3}{|c|}{ Boll weight (g) } & \multicolumn{3}{|c|}{ Length (Upper-Half Mean) } \\
\hline & Aldicarbw $^{w}$ & Disulfoton $^{x}$ & Meany & Aldicarbw & Disulfoton $^{x}$ & Meany \\
\hline Chembred 333 & 5.6 & 5.1 & $5.3 \mathrm{~b}$ & 1.13 & 1.11 & $1.13 \mathrm{ab}$ \\
\hline Deltapine 20 & 5.5 & 5.1 & $5.3 \mathrm{~b}$ & 1.12 & 1.11 & $1.12 \mathrm{~b}$ \\
\hline Deltapine 51 & 5.1 & 4.9 & $5.0 \mathrm{bc}$ & 1.17 & 1.13 & $1.15 \mathrm{a}$ \\
\hline Deltapine 5690 & 4.8 & 4.6 & $4.7 \mathrm{~cd}$ & 1.13 & 1.10 & $1.12 \mathrm{~b}$ \\
\hline DES 119 & 4.5 & 4.7 & $4.6 \mathrm{~d}$ & 1.14 & 1.13 & $1.14 \mathrm{ab}$ \\
\hline Hyperformer HS-46 & 4.8 & 4.8 & $4.8 \mathrm{~cd}$ & 1.14 & 1.12 & $1.13 \mathrm{ab}$ \\
\hline Stoneville LA-887 & 6.2 & 5.7 & $6.0 \mathrm{a}$ & 1.17 & 1.11 & $1.14 \mathrm{ab}$ \\
\hline Suregrow 501 & 5.0 & 4.8 & $4.9 \mathrm{~cd}$ & 1.12 & 1.11 & $1.12 \mathrm{~b}$ \\
\hline Mean & $5.2^{\mathrm{z}}$ & 5.0 & & $1.14^{\mathrm{z}}$ & 1.12 & \\
\hline
\end{tabular}

${ }^{\mathrm{w}}$ Temik $15 \mathrm{G}$ applied at $1.18 \mathrm{~kg}$ a.i./ha in-furrow at planting.

${ }^{x}$ DiSyston $15 \mathrm{G}$ applied at $1.11 \mathrm{~kg}$ a.i./ha in-furrow at planting.

y Means within a column followed by the same letter are not significantly different according to Duncan's new multiple range test $(P=0.05)$.

${ }^{\mathrm{z}}$ Means significantly different at $P=0.01$.

Table 3. Effect of cotton cultivars and in-furrow chemicals on lint yield and lint percentage, 1995

\begin{tabular}{|c|c|c|c|c|c|c|}
\hline \multirow[b]{2}{*}{ Cultivar } & \multicolumn{3}{|c|}{ Lint (kg/ha) } & \multicolumn{3}{|c|}{ Lint (\%) } \\
\hline & Aldicarb $^{\mathbf{v}}$ & Disulfoton $^{w}$ & $\operatorname{Mean}^{x}$ & Aldicarb $^{v}$ & Disulfoton ${ }^{w}$ & $\operatorname{Mean}^{x}$ \\
\hline Chembred 333 & 304 & 277 & $290 \mathrm{~b}$ & 35.3 & 36.1 & $35.7 \mathrm{e}$ \\
\hline Deltapine 20 & 439 & 347 & 393 a & 37.5 & 37.6 & $37.6 \mathrm{bcd}$ \\
\hline Deltapine 51 & 417 & 286 & $351 \mathrm{ab}$ & 37.2 & 36.9 & $37.1 \mathrm{~d}$ \\
\hline Deltapine 5690 & 431 & 312 & $372 \mathrm{ab}$ & 37.6 & 38.3 & $38.0 \mathrm{bcd}$ \\
\hline DES 119 & 423 & 385 & $404 \mathrm{a}$ & 38.7 & 37.9 & $38.3 \mathrm{ab}$ \\
\hline Hyperformer HS-46 & 309 & 236 & $273 b$ & 37.8 & 37.0 & $37.4 \mathrm{~cd}$ \\
\hline Stoneville LA-887 & 475 & 370 & $422 \mathrm{a}$ & 39.2 & 39.0 & $39.1 \mathrm{a}$ \\
\hline Suregrow 501 & 367 & 220 & $344 \mathrm{ab}$ & 38.4 & 38.9 & $38.7 \mathrm{ab}$ \\
\hline Mean & $395^{y}$ & 317 & & $37.7^{z}$ & 37.7 & \\
\hline
\end{tabular}

v Temik $15 \mathrm{G}$ applied at $1.18 \mathrm{~kg}$ a.i./ha in-furrow at planting.

${ }^{\mathrm{w}}$ DiSyston $15 \mathrm{G}$ applied at $1.11 \mathrm{~kg}$ a.i./ha in-furrow at planting.

${ }^{x}$ Means within a column followed by the same letter are not significantly different according to Duncan's new multiple range test $(P=0.05)$.

y Means significantly different at $P=0.01$.

${ }^{\mathrm{z}}$ Means not significantly different. 
vars $(P=0.01)$, but not between in-furrow treatments in $1995(P=0.05)$. The interaction between cultivars and in-furrow treatments was not significant for any of these parameters in $1995(P=0.05)$.

Root-knot nematode J2 population densities were low or undetectable in all plots at the beginning of the season in May of both years (data not shown). J2+egg population densities in July and November were similar for 1994 and 1995. Numbers of $M$. incognita $\mathrm{J} 2$ and eggs were lower following application of aldicarb than following disulfoton at mid-season, but not at

Table 4. Effect of cotton cultivars and in-furrow chemicals on boll weight and fiber length, 1995

\begin{tabular}{|c|c|c|c|c|c|c|}
\hline \multirow[b]{2}{*}{ Cultivar } & \multicolumn{3}{|c|}{ Boll weight (g) } & \multicolumn{3}{|c|}{ Length (Upper-Half Mean) } \\
\hline & Aldicarbw $^{\text {w }}$ & Disulfoton $^{x}$ & Mean $^{y}$ & Aldicarbw $^{w}$ & Disulfoton $^{x}$ & Mean $^{y}$ \\
\hline Chembred 333 & 4.8 & 4.5 & $4.7 \mathrm{~b}$ & 1.10 & 1.08 & $1.09 \mathrm{~b}$ \\
\hline Deltapine 20 & 4.3 & 4.1 & $4.2 \mathrm{c}$ & 1.10 & 1.08 & $1.09 \mathrm{~b}$ \\
\hline Deltapine 51 & 4.3 & 4.1 & $4.2 \mathrm{c}$ & 1.13 & 1.12 & $1.12 \mathrm{a}$ \\
\hline Deltapine 5690 & 4.1 & 4.2 & $4.2 \mathrm{c}$ & 1.12 & 1.10 & $1.11 \mathrm{ab}$ \\
\hline DES 119 & 3.9 & 3.8 & $3.9 \mathrm{~d}$ & 1.13 & 1.13 & $1.13 \mathrm{a}$ \\
\hline Hyperformer HS-46 & 4.2 & 3.8 & $4.0 \mathrm{~cd}$ & 1.13 & 1.12 & $1.12 \mathrm{a}$ \\
\hline Stoneville LA-887 & 5.2 & 5.0 & $5.1 \mathrm{a}$ & 1.16 & 1.12 & $1.14 \mathrm{a}$ \\
\hline Suregrow 501 & 4.2 & 3.8 & $4.0 \mathrm{~cd}$ & 1.12 & 1.11 & $1.12 \mathrm{ab}$ \\
\hline Mean & $4.4^{\mathrm{z}}$ & 4.2 & & $1.12^{\mathrm{z}}$ & 1.11 & \\
\hline
\end{tabular}

${ }^{w}$ Temik $15 \mathrm{G}$ applied at $1.18 \mathrm{~kg}$ a.i./ha in-furrow at planting.

x DiSyston $15 \mathrm{G}$ applied at $1.11 \mathrm{~kg}$ a.i./ha in-furrow at planting.

y Means within a column followed by the same letter are not significantly different according to Duncan's new multiple range test $(P=0.05)$.

${ }^{\mathrm{z}}$ Means significantly different at $P=0.01$.

Table 5. Effect of cotton cultivars and in-furrow chemicals on number of Meloidogyne incognita second-stage juveniles and eggs per $500 \mathrm{~cm}^{3}$ soil, $1994^{\mathrm{u}}$

\begin{tabular}{|c|c|c|c|c|c|c|}
\hline \multirow[b]{2}{*}{ Cultivar } & \multicolumn{3}{|c|}{20 July } & \multicolumn{3}{|c|}{1 November } \\
\hline & Aldicarb $^{\mathbf{v}}$ & Disulfotonw & $\operatorname{Mean}^{x}$ & Aldicarb $^{\mathbf{v}}$ & Disulfoton $^{w}$ & $\operatorname{Mean}^{x}$ \\
\hline Chembred 333 & 0.50 & 1.73 & $1.11 \mathrm{a}$ & 1.46 & 1.61 & $1.54 \mathrm{a}$ \\
\hline Deltapine 20 & 1.17 & 1.84 & $1.50 \mathrm{a}$ & 1.45 & 1.42 & $1.44 \mathrm{a}$ \\
\hline Deltapine 51 & 0.25 & 2.22 & $1.23 \mathrm{a}$ & 1.04 & 1.63 & $1.33 \mathrm{a}$ \\
\hline Deltapine 5690 & 0.81 & 1.38 & $1.10 \mathrm{a}$ & 2.03 & 1.58 & $1.80 \mathrm{a}$ \\
\hline DES 119 & 0.61 & 1.72 & $1.16 \mathrm{a}$ & 1.56 & 0.84 & $1.20 \mathrm{a}$ \\
\hline Hyperformer HS-46 & 0.89 & 1.84 & $1.37 \mathrm{a}$ & 1.44 & 1.57 & $1.51 \mathrm{a}$ \\
\hline Stoneville LA-887 & 0.25 & 1.38 & $0.82 \mathrm{a}$ & 1.57 & 1.52 & $1.55 \mathrm{a}$ \\
\hline Suregrow 501 & 1.29 & 1.95 & $1.62 \mathrm{a}$ & 1.64 & 1.73 & $1.69 \mathrm{a}$ \\
\hline Mean & $0.72^{y}$ & 1.76 & & $1.49^{\mathrm{z}}$ & 1.52 & \\
\hline
\end{tabular}

u Actual populations transformed for statistical analysis; $\log ($ juveniles+eggs +1$)$.

$\mathrm{v}$ Temik $15 \mathrm{G}$ applied at $1.18 \mathrm{~kg}$ a.i./ha in-furrow at planting.

${ }^{\mathrm{w}}$ DiSyston $15 \mathrm{G}$ applied at $1.11 \mathrm{~kg}$ a.i./ha in-furrow at planting.

${ }^{x}$ Means within a column followed by the same letter are not significantly different according to

Duncan's new multiple range test $(P=0.05)$.

y Means significantly different at $P=0.01$.

${ }^{\mathrm{z}}$ Means not significantly different.

Table 6. Effect of cotton cultivars and in-furrow chemicals on number of Meloidogyne incognita second-stage juveniles and eggs per $500 \mathrm{~cm}^{3}$ soil, $1995^{\mathrm{u}}$

\begin{tabular}{|c|c|c|c|c|c|c|}
\hline \multirow[b]{2}{*}{ Cultivar } & \multicolumn{3}{|c|}{21 July } & \multicolumn{3}{|c|}{3 November } \\
\hline & Aldicarbv & Disulfoton $^{w}$ & $\operatorname{Mean}^{\mathrm{x}}$ & Aldicarbv $^{\mathbf{v}}$ & Disulfoton $^{w}$ & $\operatorname{Mean}^{\mathrm{x}}$ \\
\hline Chembred 333 & 1.15 & 1.47 & $1.31 \mathrm{ab}$ & 2.67 & 2.12 & $2.39 \mathrm{a}$ \\
\hline Deltapine 20 & 0.89 & 2.19 & $1.54 \mathrm{a}$ & 2.15 & 2.43 & $2.29 \mathrm{a}$ \\
\hline Deltapine 51 & 1.22 & 1.98 & $1.60 \mathrm{a}$ & 2.29 & 2.14 & $2.21 \mathrm{a}$ \\
\hline Deltapine 5690 & 1.27 & 1.82 & $1.55 \mathrm{a}$ & 2.37 & 2.51 & $2.44 \mathrm{a}$ \\
\hline DES 119 & 1.81 & 1.94 & $1.88 \mathrm{a}$ & 2.52 & 2.47 & $2.49 \mathrm{a}$ \\
\hline Hyperformer HS-46 & 1.65 & 1.87 & $1.76 \mathrm{a}$ & 2.44 & 2.41 & $2.42 \mathrm{a}$ \\
\hline Stoneville LA-887 & 0.44 & 0.68 & $0.56 \mathrm{~b}$ & 2.01 & 2.28 & $2.15 \mathrm{a}$ \\
\hline Suregrow 501 & 0.78 & 1.79 & $1.29 \mathrm{ab}$ & 2.41 & 2.45 & $2.43 \mathrm{a}$ \\
\hline Mean & $1.15^{\mathrm{y}}$ & 1.72 & & $2.35^{\mathrm{z}}$ & 2.35 & \\
\hline
\end{tabular}

u Actual populations transformed for statistical analysis; $\log (j u v e n i l e s+e g g s+1)$.

$\mathrm{v}$ Temik $15 \mathrm{G}$ applied at $1.18 \mathrm{~kg}$ a.i./ha in-furrow at planting.

${ }^{w}$ DiSyston $15 \mathrm{G}$ applied at $1.11 \mathrm{~kg}$ a.i./ha in-furrow at planting.

${ }^{x}$ Means within a column followed by the same letter are not significantly different according to

Duncan's new multiple range test $(P=0.05)$.

y Means significantly different at $P=0.01$.

${ }^{\mathrm{z}}$ Means not significantly different.

harvest (Tables 5 and 6). No differences in numbers of $\mathrm{J} 2+$ eggs were found among cultivars either at mid-season or at the end of the season except in July of 1995. The interaction between cultivars and in-furrow treatments was not significant for $\mathbf{J} 2+$ egg populations at any sampling period in either year $(P=0.05)$.

Root gall ratings among cultivars and between in-furrow treatments were similar in 1994 and 1995, but mean ratings were higher in 1995 (Table 7). In both years, root gall ratings were $23 \%$ lower across cultivars in the aldicarb-treated plots. Gall ratings were different among cultivars both years $(P=0.01)$. The cultivar $\times$ in-furrow treatment interaction was significant in $1994(P=0.05)$, but not in $1995(P=$ 0.05). Stoneville LA887 had the lowest root gall ratings among cultivars in both years.

Although mean wilt ratings were lower in 1994 than 1995, the results were similar (Table 8). The highest wilt ratings were 1.2 and 3.5 in 1994 and 1995, respectively. In 1994 and 1995, wilt ratings were 37.5 and $30.4 \%$ lower, respectively, in the aldicarb plots. Wilt ratings were different among cultivars both years $(P=0.01)$, but the interaction between cultivars and in-furrow treatments was not significant either year $(P=0.05)$. In 1995 , Stoneville LA887 had significantly lower wilt ratings, whereas Hyperformer HS-46 had higher wilt ratings than the other cultivars. Fusarium oxysporum was consistently recovered from stem sections displaying vascular discoloration.

\section{DISCUSSION}

The relative effects of in-furrow treatments and cultivars on lint yields were similar both years, but seed cotton and lint yields were lower in 1995 than in 1994 due to extremely dry conditions. Total rainfall from planting to harvest for 1994 and 1995 was 66.07 and $30.61 \mathrm{~cm}$, respectively. During May and June, total rainfall in 1994 was $11.02 \mathrm{~cm}$ compared with only $3.81 \mathrm{~cm}$ in 1995. July rainfall was similar in 1994 and 1995 (11.71 versus $11.07 \mathrm{~cm})$, but in August $8.36 \mathrm{~cm}$ was reported in 1994 compared with $4.06 \mathrm{~cm}$ in 1995.

The application of aldicarb improved lint yield both years and lint percentage in 1994, and reduced the severity of the rootknot nematode-Fusarium wilt disease complex both years. Other researchers have improved cotton yields and reduced root galling caused by the root-knot nematode with the application of in-furrow nematicides (14), but the effect of these pesticides on the root-knot nematode-Fusarium wilt disease complex has not been evaluated. The severity of the root-knot nematode-Fusarium wilt complex in cotton has been reduced with the use of soil fumigants $(9,11)$. In addition to reducing nematode populations in the soil, some fumigants may affect survival of the wilt 
fungus in the soil (7). The ability of aldicarb to reduce the severity of the rootknot nematode-Fusarium wilt disease complex in this study is probably related to its impact on numbers of $M$. incognita, which were reduced in July both years. It has been demonstrated previously that management of root-knot nematodes reduces the severity of Fusarium wilt $(12,16,17)$.

Cotton cultivars differ in yield potential and fiber qualities. Some of the observed differences in lint yield, lint percentage, boll size, and fiber length among cultivars may have been the result of differences in yield potential among cultivars, whereas others may have been the result of different levels of resistance to the root-knot nematode-Fusarium wilt disease complex. The disease complex often reduces cotton yields $(5,7,11,21)$. Veech (23) reported shorter fiber length, reduced seed cotton yield, and fewer bolls associated with nematode infection. Large bolls, reduced root galling, and wilt-related stem discoloration for Stoneville LA887 were not un- expected. Upon release, this cultivar was reported to produce large bolls with high yield potential and improved root-knot nematode-Fusarium wilt resistance (10), and it has performed well in statewide evaluations (4).

The application of aldicarb in-furrow at planting reduced the severity of the rootknot nematode-Fusarium wilt complex in cotton and improved lint yield, lint percentage, and boll size. Although some of these improvements may be related to yield potential among cultivars, it is apparent that the reduction in the disease complex was also involved. More thorough investigation of the contribution of reducing nematode population density with nematicides to the overall severity of the root-knot nematode-Fusarium wilt disease complex may allow more cost-effective management strategies to be developed.

\section{ACKNOWLEDGMENTS}

We thank J. I. Dickson and his staff at the Louisiana Agricultural Experiment Station Cotton Fiber Laboratory for their assistance in providing fiber data.

Table 7. Effect of cotton cultivars and in-furrow chemicals on root gall ratings, 1994 and 1995

\begin{tabular}{|c|c|c|c|c|c|c|}
\hline \multirow[b]{3}{*}{ Cultivar } & \multicolumn{6}{|c|}{ Root gall rating ${ }^{v}$} \\
\hline & \multicolumn{3}{|c|}{1994} & \multicolumn{3}{|c|}{1995} \\
\hline & Aldicarb $^{w}$ & Disulfoton $^{x}$ & Mean $^{y}$ & Aldicarb $^{w}$ & Disulfoton $^{x}$ & Mean $^{y}$ \\
\hline Chembred 333 & 2.0 & 3.7 & $2.8 \mathrm{a}$ & 3.1 & 4.0 & $3.6 \mathrm{~b}$ \\
\hline Deltapine 20 & 2.0 & 2.7 & $2.4 \mathrm{ab}$ & 3.4 & 4.6 & $4.0 \mathrm{ab}$ \\
\hline Deltapine 51 & 1.6 & 2.3 & $2.0 \mathrm{~b}$ & 3.3 & 4.5 & $3.9 \mathrm{ab}$ \\
\hline Deltapine 5690 & 2.3 & 2.5 & $2.4 \mathrm{ab}$ & 3.5 & 4.9 & $4.2 \mathrm{ab}$ \\
\hline DES 119 & 2.4 & 3.1 & $2.7 \mathrm{a}$ & 3.7 & 4.8 & $4.2 \mathrm{ab}$ \\
\hline Hyperformer HS-46 & 2.2 & 2.9 & $2.6 \mathrm{a}$ & 4.4 & 4.7 & $4.6 \mathrm{a}$ \\
\hline Stoneville LA-887 & 1.2 & 1.3 & $1.2 \mathrm{c}$ & 1.5 & 2.0 & $1.8 \mathrm{c}$ \\
\hline Suregrow 501 & 2.3 & 2.6 & $2.5 \mathrm{a}$ & 3.2 & 4.8 & $4.0 \mathrm{ab}$ \\
\hline Mean & $2.0^{\mathrm{z}}$ & 2.6 & & $3.3^{z}$ & 4.3 & \\
\hline
\end{tabular}

${ }^{\mathrm{v}}$ Root gall rating on a scale of 0 to $5: 0=$ no root galling, $5=$ severe root galling.

${ }^{\mathrm{w}}$ Temik $15 \mathrm{G}$ applied at $1.18 \mathrm{~kg}$ a.i./ha in-furrow at planting.

${ }^{x}$ DiSyston $15 \mathrm{G}$ applied at $1.11 \mathrm{~kg}$ a.i./ha in-furrow at planting.

${ }^{y}$ Means within a column followed by the same letter are not significantly different according to

Duncan's new multiple range test $(P=0.05)$.

${ }^{\mathrm{z}}$ Means significantly different at $P=0.01$.

Table 8. Effect of cotton cultivars and in-furrow chemicals on wilt ratings, 1994 and 1995

\begin{tabular}{|c|c|c|c|c|c|c|}
\hline \multirow[b]{3}{*}{ Cultivar } & \multicolumn{6}{|c|}{ Wilt ratingv } \\
\hline & \multicolumn{3}{|c|}{1994} & \multicolumn{3}{|c|}{1995} \\
\hline & Aldicarb $^{w}$ & Disulfoton $^{x}$ & $\operatorname{Mean}^{\mathrm{y}}$ & Aldicarb $^{w}$ & Disulfoton $^{x}$ & Mean $^{y}$ \\
\hline Chembred 333 & 0.5 & 1.1 & $0.8 \mathrm{ab}$ & 1.8 & 2.2 & $2.0 \mathrm{bc}$ \\
\hline Deltapine 20 & 0.4 & 0.4 & $0.4 \mathrm{~b}$ & 1.6 & 2.3 & $1.9 \mathrm{bc}$ \\
\hline Deltapine 51 & 0.4 & 0.7 & $0.6 a b$ & 1.9 & 3.0 & $2.5 \mathrm{~b}$ \\
\hline Deltapine 5690 & 0.5 & 0.9 & $0.7 \mathrm{ab}$ & 1.2 & 2.6 & $1.9 \mathrm{c}$ \\
\hline DES 119 & 0.5 & 0.7 & $0.6 a b$ & 1.2 & 1.7 & $1.5 \mathrm{c}$ \\
\hline Hyperformer HS-46 & 0.8 & 1.2 & $1.0 \mathrm{a}$ & 3.3 & 3.5 & $3.4 \mathrm{a}$ \\
\hline Stoneville LA-887 & 0.1 & 0.5 & $0.3 \mathrm{~b}$ & 0.6 & 0.6 & $0.6 \mathrm{~d}$ \\
\hline Suregrow 501 & 0.5 & 0.9 & $0.7 \mathrm{ab}$ & 1.5 & 2.6 & $2.0 \mathrm{bc}$ \\
\hline Mean & $0.5^{z}$ & 0.8 & & $1.6^{\mathrm{z}}$ & 2.3 & \\
\hline
\end{tabular}

${ }^{\mathrm{v}}$ Wilt rating on a scale of 0 to $5: 0=$ no vascular discoloration, $5=$ entire vascular ring discolored.

${ }^{\mathrm{w}}$ Temik $15 \mathrm{G}$ applied at $1.18 \mathrm{~kg}$ a.i./ha in-furrow at planting.

${ }^{x}$ DiSyston $15 \mathrm{G}$ applied at $1.11 \mathrm{~kg}$ a.i./ha in-furrow at planting.

${ }^{y}$ Means within a column followed by the same letter are not significantly different according to Duncan's new multiple range test $(P=0.05)$.

${ }^{\mathrm{z}}$ Means significantly different at $P=0.01$.

\section{LITERATURE CITED}

1. Ayoub, S. M. 1980. Plant Nematology: An Agricultural Training Aid. NemaAid Publications, Sacramento, CA.

2. Bird, L. S. 1981. Pest management systems for cotton diseases. Pages 203-213 in: Handbook of Pest Management in Agriculture. Vol. 3. D. Pimentel, ed. CRC Press, Boca Raton, FL.

3. Bird, L. S. 1986. Tactics for maintaining plant health of cotton. Plant Dis. 70:477-479.

4. Caldwell, W. D., Griffin, R. C., Boquet, D. J., Colyer, P. D., and Vernon, P. R. 1994. 1994 Cotton cultivar trials in Louisiana. La. Agric. Exp. Sta. Mimeo Series No. 99.

5. DeVay, J. E. 1986. Half a century dynamics and control of cotton diseases: Fusarium and Verticillium wilt. Pages 35-40 in: 1986 Proc. Beltwide Cotton Prod. Conf.

6. Garber, R. H., DeVay, J. E., and DeTar, W. R. 1992. Comparisons of cotton cultivars and chemicals for control of the Fusarium/rootknot nematode complex in Fusarium wilt. Page 203 in: 1992 Proc. Beltwide Cotton Prod. Res. Conf.

7. Hillocks, R. J. 1992. Fusarium wilt. Pages 127-160 in: Cotton Diseases. R. J. Hillocks, ed. CAB Int., Wallingford, U.K.

8. Hussey, R. S., and K. R. Barker. 1973. A comparison of methods of collecting inocula or Meloidogyne spp., including a new technique. Plant Dis. Rep. 57:1025-1028.

9. Hyer, A. H., Jorgenson, E. C., Garber, R. H., and Smith, S. 1979. Resistance to root-knot nematode in control of root-knot nematodeFusarium wilt disease complex in cotton. Crop Sci. 19:898-901.

10. Jones, J. E., Dickson, J. I., Aguillard, W., Caldwell, W. D., Moore, S. H., Hutchinson, R. L., and Rogers, R. L. 1991. Registration of 'LA 887' cotton. Crop Sci. 31:1701.

11. Jorgenson, E. C., Hyer, A. H., Garber, R. H., and Smith, S. N. 1978. Influence of soil fumigation on the Fusarium-root-knot nematode disease complex of cotton in California. J. Nematol. 10:228-231.

12. Kappelman, A. J., Jr., and Sappenfield, W. P. 1973. Development of a set of upland cotton lines for comparisons of Fusarium-root-knot nematode disease complex of cotton in California. Crop Sci. 13:280-281.

13. Kappelman, A. J., Jr., and Smith, S. N. 1981. Fusarium wilt-nematode complex. Pages $40-$ 41 in: Compendium of Cotton Diseases. G M. Watkins, ed. American Phytopathological Society, St. Paul, MN.

14. Kirkpatrick, T. L. 1994. Efficacy of Temik $15 \mathrm{G}$ for root-knot nematode control in cotton. Pages 123-127 in: Proc. 1993 Cotton Res. Meet. 1993 Summ. Cotton Res. in Prog. D M. Oosterhuis, ed. Arkansas Agric. Exp. Sta. Spec. Rep. 162.

15. Mai, W. F., and Abawi, G. S. 1987. Interactions among root-knot nematodes and Fusarium wilt fungi on host plants. Ann. Rev. Phytopathol. 25:317-338.

16. Martin, W. J., Newsom, L. D., and Jones, J. E. 1956. Relationship of nematodes to the development of Fusarium wilt in cotton. Phytopathology 46:285-289.

17. Minton, N. A., and Minton, E. B. 1966. Effect of root knot and sting nematodes on expression of Fusarium wilt of cotton in three soils. Phytopathology 56:319-322.

18. Shepherd, R. L. 1986. Cotton resistance to the root knot-Fusarium wilt complex. II. Relation to root-knot resistance and its implications on breeding for resistance. Crop Sci. 26:233-237.

19. Shepherd, R. L., and Kappelman, A. J. 1986. Cotton resistance to the root knot-Fusarium wilt complex. I. Relation to Fusarium wilt resistance and its implications on breeding for 
resistance. Crop Sci. 26:227-232.

20. Smith, S. N., and Snyder, W. C. 1975. Persistence of Fusarium oxysporum f. sp. vasinfectum in fields in the absence of cotton. Phytopathology 65:190-196.

21. Starr, J. L., Jeger, M. J., Martyn, R. D., and
Schilling, K. 1989. Effects of Meloidogyne incognita and Fusarium oxysporum f. sp. vasinfectum on plant mortality and yield of cotton. Phytopathology 79:640-646.

22. Starr, J. L., and Smith, C. W. 1993. Root-knot nematodes and Fusarium wilt resistance to both pathogens. Pages 178-179 in: 1993 Proc. Beltwide Cotton Prod. Conf.

23. Veech, J. A. 1991. The effect of nematode infection on cotton fiber quality and yield: the issue revisited. Page 190 in: 1991 Proc. Beltwide Cotton Conf. 